\title{
A Cryptobia salmositica (Kinetoplastida: Sarcomastigophora) species-specific DNA probe and its uses in salmonid cryptobiosis
}

\author{
S. Li, P. T. K. Woo* \\ Department of Zoology, University of Guelph, Guelph, Ontario, Canada N1G 2W1
}

\begin{abstract}
A Cryptobia salmositica DNA probe (Cs-V1), of approximately 1.2 kilo base-pairs (kb), was developed from an avirulent strain of the pathogen. Nuclear DNA of C. salmositica was isolated, cleaved with Hind III, cloned, and labelled with non-radioactive digoxigenin. CS-V1 hybridized specifically with C. salmositica DNA and there were no cross-hybridizations between the probe and DNA from $C$. borreli, $C$. bullocki and $C$. catostomi. A potentially useful identification/diagnostic technique for C. salmositica was developed using blood dried on filter paper The dried blood DNA dot blot (DBDB) technique distinguished C. salmositica from C. catostomi, C. bullocki and C. borreli and it was also used for the diagnosis of $C$. salmositica infection in fish. The technique does not require DNA purification and the probe does not cross-hybridize with rainbow trout blood DNA. Less than $20 \mu l$ of fish blood (which contains approximately 100000 organisms $\mathrm{ml}^{-1}$ ) is required using the DBDB technique.
\end{abstract}

KEY WORDS: Cryptobia salmositica DNA probe Cryptobiosis Diagnosis - Rainbow trout

\section{INTRODUCTION}

Cryptobia salmositica is a pathogenic haemoflagellate of salmonids in western North America (Woo 1987 1994). It causes cryptobiosis in experimentally infected rainbow trout Oncorhynchus mykiss (see Woo 1979). C. salmositica was presumed to be non-host-specific by some workers and hence it has been reported from all species of Oncorhynchus in North America and from many other species of freshwater teleosts (Becker \& Katz 1965, Katz et al. 1966, Bower \& Margolis 1984). However, Woo (1987) suggested that some Cryptobia in non-salmonid fishes on the west coast of North America may not be C. salmositica. Unfortunately, $C$. salmositica is morphologically similar to other Cryptobia spp. To better understand the epizootiology of cryptobiosis, it would be useful to have a relatively rapid and simple technique to distinguish $C$. salmositica from other Cryptobia spp. The purpose of the

·E-mail: pwoo@uoguelph.ca present study was to develop a C. salmositica-specific DNA probe to distinguish $C$. salmositica from other Cryptobia spp. and perhaps also to use it for diagnosis of infections in fishes

One method to develop a DNA probe is by cloning highly repetitive species-specific nuclear DNA fragments (Kirchhoff \& Donelson 1993). In most trypanosome species, the species-specific repetitive DNA fragments constitute up to $9 \%$ of nuclear DNA (Gonzalez et al. 1984, Kirchhoff \& Donelson 1993). Thus, such repetitive specific DNA fragments are likely to be cloned and be used as species-specific probes (Massamba \& Williams 1984, Kukla et al. 1987). In the present study, a Cryptobia salmositica-specific DNA probe was developed by cloning repetitive nuclear DNA fragments from a cloned vaccine strain of $C$. salmositica.

\section{MATERIALS AND METHODS}

Species of Cryptobia. The pathogenic Cryptobia salmositica used in the present study was initially iso- 
lated from its leech vector and maintained in rainbow trout (Woo 1978). It was subsequently isolated from the blood of one of these trout and maintained in Minimum Essential Medium (MEM) at $10^{\circ} \mathrm{C}$ (Woo \& Li 1990, Li \& Woo 1991) for no more than $8 \mathrm{wk}$ at which time it would still be pathogenic to trout (Woo \& Thomas 1991j. The pathogen was attenuated by continuous in vitro culture and used as a vaccine (Woo \& Li 1990), which was cloned as described (Gradoni et al. 1983). Briefly, the number of parasites in a 2 wk culture was determined using a haemocytometer (Archer 1965) and diluted with the sterile culture medium until there were approximately 170 parasites $\mathrm{ml}^{-1}$ (i.e. 1 parasite per droplet of $0.006 \mathrm{ml}$ ). A single droplet was dispensed into each of 7 wells (in a luw) of a sterile 96-well (U-shape) cuilture plate which was covered and kept on ice. The droplets were examined carefully at $0,24,48$ and $72 \mathrm{~h}$ using an inverted microscope (100 magnifications). Ice-cold fresh medium $(0.2 \mathrm{ml})$ was added at $0 \mathrm{~h}$ to each of those wells which contained a single parasite. The 3 rows of wells on both sides of these 7 wells (with parasites) were filled with sterile distilled water to maintain a high humidity. Two weeks later, each of the established cloned $C$. salmositica vaccine strains was transferred to a Falcon culture flask $\left(25 \mathrm{~cm}^{2}\right)$ containing $10 \mathrm{ml}$ of the medium and incubated at $10^{\circ} \mathrm{C}$ as described earlier (Li \& Woo 1991). Smears were made from each cloned parasite, stained with Giemsa's stain and examined using a compound microscope. All strains of $C$. salmositica were maintained continuously in MEM at $10^{\circ} \mathrm{C}$.

Cryptobia bullocki, a pathogenic haemoflagellate of the summer flounder Paralichthys dentatus, was maintained in MEM at $10^{\circ} \mathrm{C}$ (Woo 1987) and C. catostomi, a nonpathogenic haemoflagellate of white suckers Catostomus commersoni, was isolated from an infected white sucker and maintained in the modified TDL-15 medium at $10^{\circ} \mathrm{C}$ (Li \& Woo in press). C. borreli, a pathogenic haemoflagellate of the carp Cyprinus carpio, was maintained in infected carp at $24^{\circ} \mathrm{C}$. The pathogen was kindly provided by Prof. W. B. van Muiswinkel, Wageningen Agricultural University, The Netherlands.

Isolation of nuclear DNA. The method for nuclear DNA isolation was modified from Lynn \& Sogin (1988). Briefly, Cryptobia bullocki, C. catostomi and the 5 strains of $C$. salmositica, each consisting of approximately $100 \times 10^{6}$ parasites (determined using a haemocytometer; Archer 1965) in $20 \mathrm{ml}$ of medium were collected by centrifugation at $2600 \times g$ for $20 \mathrm{~min}$ at $4^{\circ} \mathrm{C}$ in a Hitachi automatic high speed refrigerated centrifuge (Model CR20B2, Hitachi Koki, Tokyo, Japan). Parasites were suspended in $1 \mathrm{ml}$ of STE buffer $(0.1 \mathrm{M} \mathrm{NaCl}$, $0.01 \mathrm{M}$ Tris and $0.001 \mathrm{M}$ EDTA, pH 8.0) and then lysed with additional sodium dodecyl sulfate (SDS) at $1 \%$ (w/v) of final concentration. Nuclear DNA was separated from kinetoplast DNA by centrifugation at 54000 $\times g$ for 1 h (Fairlamb et al. 1978). Nuclear DNA was extracted, precipitated and resuspended in TE buffer (0.01 M Tris-HCl and 0.001 M EDTA, pH 8.0) (Sambrook et al. 1989). The amount of the nuclear DNA was determined using a Gene Quant RNA/DNA Calculator (Pharmacia LKB Biochrom Ltd, England).

Fish blood $(1 \mathrm{ml})$ with Cryptobia borreli was collected from an infected carp (infected intraperitoneally with $1000000 \mathrm{C}$. borreli) by a caudal vein puncture at $3 \mathrm{wk}$ post infection. The blood was suspended in $10 \mathrm{ml}$ of TE in a centrifuge tube and let stand for $30 \mathrm{~min}$ at room temperature. The supernatant $(7 \mathrm{ml})$ containing approximately 20000000 parasites and 65000 fish blood colls determined using a haemocytometer were transferred to another centrifuge tube. $C$. borreli with fish blood cells was collected by centrifugation as described earlier

Preparation of a Cs-V1 probe from Cryptobia salmositica nuclear DNA. The purified nuclear DNA $(5 \mu \mathrm{g})$ of the cloned vaccine strain (Cs-c) of C. salmositica was cleaved with a restriction endonuclease Hind III (10 U $\mu^{-1} \mathrm{DNA}_{i}$ Promega, Madison, WI, USA) and fragments were separated using electrophoresis in $0.8 \%$ agarose gel at 100 v for $2 \mathrm{~h}$ (PowerPac 300; BioRad, Melville, NY, USA). A distinct DNA band (approximately 1.2 kilo base-pairs; kb) stained with ethidium bromide was sliced and extracted from the agarose gel by centrifugation (Heery et al. 1990). The DNA fragment named Cs-V1 was cloned using a plasmid vector (Pbluescript, SK, $2.9 \mathrm{~kb}$; Stratagene, La Jolla, CA, USA), amplified in Escherichia coli (DH.5 $\alpha$ F; GIBCOBRL, Burlington, ON, Canada) and isolated as described (Sambrook et al. 1989). The Cs-V1 fragments were labelled with non-radioactive digoxigenin-11-dUTP (DIG) according to the manufacturer's instructions (Boehringer Mannheim, Laval, PQ, Canada).

Southern blot hybridizations. Nuclear DNA $(0.5 \mu \mathrm{g})$ from Cryptobia salmositica, C. borreli, C. bullocki and C. catostomi was cleaved with Hind III, and were separated by electrophoresis in $1.0 \%$ agarose gel at $24 \mathrm{~V}$ for $12 \mathrm{~h}$. DNA fragments (target DNA) in the gel were denatured in a denature solution. $(1.5 \mathrm{M} \mathrm{NaCl}, 0.5 \mathrm{~N}$ $\mathrm{NaOH}$ ) and neutralized in a neutralization solution (1.0 M Tris- $\mathrm{HCl}$ and $1.5 \mathrm{~N} \mathrm{NaCl}, \mathrm{pH} 8.0)$. The denatured target DNA fragments were transferred from the gel onto a nylon membrane (Boehringer Mannheim) using a VacuGene XL blotting unit at 40 millibars (Pharmacia LKB Biochrom Ltd, England) and were fixed onto the membrane at $80^{\circ} \mathrm{C}$ for $2 \mathrm{~h}$ (Southern 1975). DNA hybridization with the DIG-labelled Cs-V1 probe was performed according to the manufacturer's instructions (Boehringer Mannheim). 
Dried blood DNA dot blot (DBDB) technique. Cryptobia bullocki, C. catostomi from cultures and the pathogenic C. salmositica (with trout blood) from an infected rainbow trout and $C$. borreli (with carp blood) from an infected carp were concentrated as described earlier and added to ice-cold heparinized naive trout blood which was preheated at $45^{\circ} \mathrm{C}$ for $30 \mathrm{~min}$ to inactivate the complement (Sakai 1981). The short term heat treatment did not cause visible changes (e.g. haemolysis) to the blood. The number of parasites was estimated using a haemocytometer and was diluted with trout blood until there were approximately 1000000 parasites $\mathrm{ml}^{-1}$ of blood. A volume of $0.02 \mathrm{ml}$ blood and parasites from each dilution was dispensed onto a Whatman filter paper (No. 5), air-dried and stored in a sealed plastic bag at $-20^{\circ} \mathrm{C}$ until used.

A disc (6 mm diameter) of the filter paper with dried blood and parasites was cut with a paper puncher and the disc was incubated with $0.2 \mathrm{ml}$ of TE in a microcentrifuge tube at $24^{\circ} \mathrm{C}$ for $1 \mathrm{~h}$ on a shaker $(60$ cycles $\left.\mathrm{min}^{-1}\right)$. Each disc was rinsed with another $0.2 \mathrm{ml}$ of $\mathrm{TE}$ The DNA in the pooled elute $(0.4 \mathrm{ml})$ was extracted and precipitated (as described in Sambrook et al 1989). Each DNA sample from 1 disc was resuspended in $0.005 \mathrm{ml}$ of $\mathrm{TE}$, blotted onto the nylon membrane and air-dried at $24^{\circ} \mathrm{C}$. The DNA was denatured by laying the nylon membrane on a Whatman filter paper (No. 5) saturated with a denature solution for $10 \mathrm{~min}$ and then on another filter paper saturated with a neutralization solution for another 10 min. The DNA was fixed onto the membrane and hybridized with the Cs-V1 probe as described earlier. Similarly, purified nuclear DNA (see 'Isolation of nuclear DNA') of pathogenic Cryptobia salmositica (7.5 ng), C. bullocki $(9.5$ ng), C. catostomi ( $8.9 \mathrm{ng})$, and crude DNA of C. borreli $(9.0 \mathrm{ng})$ and fish blood DNA $(6.7 \mu \mathrm{g})$ were also blotted on filter paper and hybridized with the probe.

Standardization of the DBDB technique. The cloned vaccine strain of Cryptobia salmositica (Cs-c) from culture was washed once in STE and added to rainbow trout blood. The number of $C$. salmositica was determined using a haemocytometer and this was subsequently diluted with trout blood so that the final concentrations ranged from 1000 to 1000000 C. salmositica $\mathrm{ml}^{-1}$. Blood at each dilution was examined for parasites using the haematocrit centrifuge technique (HCT; Woo 1969, Woo \& Wehnert 1983). Also, each blood dilution $(0.02 \mathrm{ml})$ was dispensed onto Whatman filter paper (No. 5) and air-dried. The DBDB technique was applied to the dried blood as described earlier.

Diagnosis of Cryptobia salmositica in experimentally infected fish using the DBDB technique. Four rainbow trout $(226.3 \pm 12.7 \mathrm{~g})$ were tagged and each was infected intraperitoneally with 100000 pathogenic C. salmositica from an infected trout. The fish were maintained in continuous fresh well water with aeration at $10 \pm 2^{\circ} \mathrm{C}$. Blood samples $\left(0.4 \mathrm{ml} \mathrm{fish}^{-1}\right)$ were collected weekly by caudal vein punctures before and after the infection (Li \& Woo 1991). Parasites were detected using the HCT and counted using a haemocytometer. A volume of $0.02 \mathrm{ml}$ of blood sample was dispensed onto Whatman filter paper (No. 5), air-dried and stored in sealed plastic bags at $-20^{\circ} \mathrm{C}$ until the DBDB was performed.

\section{RESULTS}

In the cloning experiment, 3 of 7 wells contained a single Cryptobia salmositica, the other 4 wells either contained 2 parasites (in 3 wells) or no parasites (in 1 well). The 3 cloned vaccine strains were named Cs-C, Cs-d and Cs-e, and they were morphologically similar to the uncloned vaccine strain. The generation time of the cloned strain was approximately $48 \mathrm{~h}$ during the first $3 \mathrm{~d}$ after cloning

One distinctive DNA band (approximately $1.2 \mathrm{~kb}$ ) cleaved with Hind III was consistently found only in Cryptobia salmositica nuclear DNA (vaccine and pathogenic strains) but not in other Cryptobia spp. (Fig 1). The DNA was cloned, amplified, isolated and labelled with non-radioactive DIG to produce the Cs-V1 probe

The Cs-V1 probe hybridized with Hind III cleaved nuclear DNA fragments from all 5 strains of Cryptobia salmositica (Southern blot hybridization). The hybridization band was intense with $1.2 \mathrm{~kb}$ DNA fragments (Fig, 2). Another C. salmositica DNA fragment (approx-

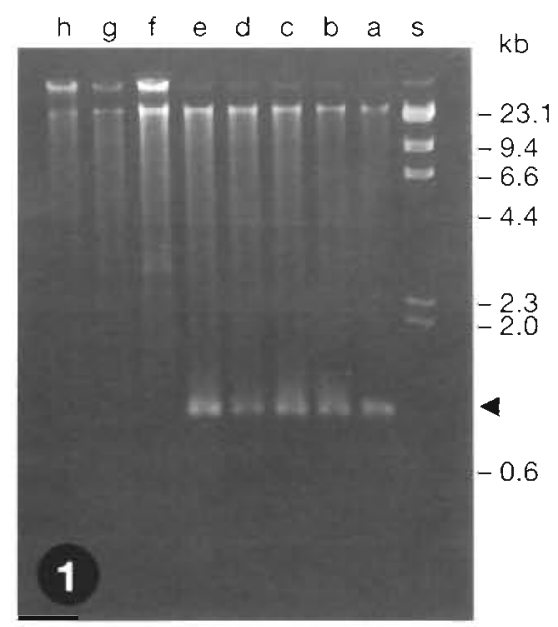

Fig. 1. Cryptobia spp. Electrophoresis (1.0\% agarose) of Hind III cleaved nuclear D. V. I fragments. Lane a: pathogenic strain of C. salmositica; lane b: vaccine strain of C. salmositica; lanes c to e: 3 C. salmositica vaccine clones (Cs-C, Cs-d

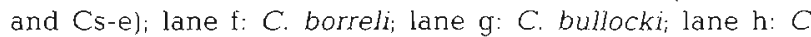
catostomi; lane s: DNA standard size markers (arrow indicates $1.2 \mathrm{~kb}$ DNA fragment) 


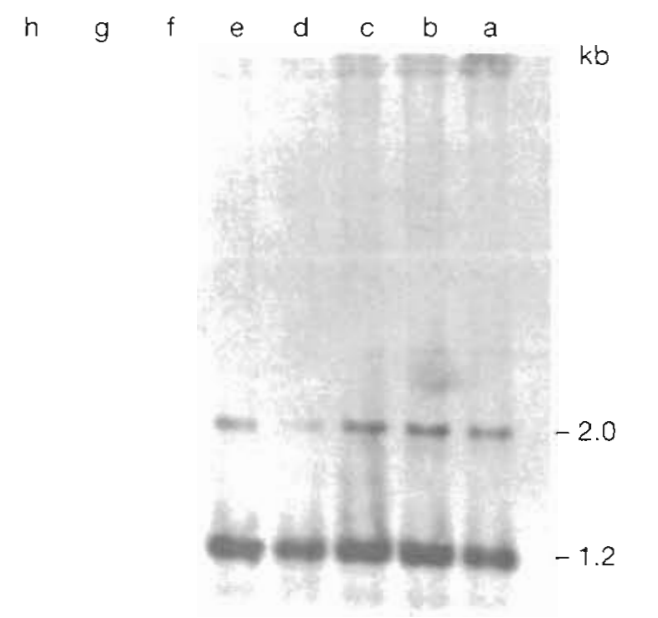

2

Fig. 2. Cryptobia spp. Hybridization of cleaved nucleic DNA fragments with DIG-labelled Cs-V1 probe. Lane a: pathogenic strain of $C$. salmositica; lane b: vaccine strain of $C$. salmositica; lanes c to e: 3 C. salmositica vaccine clones (Cs-C, $\mathrm{Cs}-\mathrm{d}$ and $\mathrm{Cs}-\mathrm{e})$; lane f: C. borreli lane g: C. bullocki; lane h:

$$
\text { C. catostomi }
$$

imately $2.0 \mathrm{~kb}$ ) also hybridized with the Cs-V1 probe but the band was not as intense as with the $1.2 \mathrm{~kb}$ DNA fragments. There were no cross-hybridizations between the Cs-V1 probe and cleaved DNA from $C$. catostomi, C. borreli, or C. bullocki.

Using the DBDB technique, the Cs-V1 probe hybridized only with homologous target Cryptobia salmositica DNA, which was either purified nuclear DNA (of parasite from cultures) or crude DNA (parasites in fish blood). There were no cross-hybridizations between the Cs-V1 probe and DNA from other Cryptobia spp. which were either purified nuclear DNA or crude DNA. There was also no cross-hybridization between. the Cs-V1 probe and a massive amount of fish blood. DNA (Figs. 3 \& 4). C. salmositica (in the experiment on standardization of the DBDB technique) was detected using the HCT when there were about 1000 to 1000000 parasites $\mathrm{ml}^{-1}$ in fish blood. However, parasite DNA (in not more than $0.02 \mathrm{ml}$ of dried fish blood) from filter paper was detected using the DBDB technique when there were approximately 100000 parasites $\mathrm{ml}^{-1}$ of fish blood (Fig. 5).

Using the HCT (Table 1), parasites were detected at 2 wk post-infection in 3 experimentally infected fish (Nos. 2 to 4 ) and at 4 wk post-infection in the remaining fish (No. 1). However, Cryptobia salmositica DNA was first detected using the DBDB technique at $3 \mathrm{wk}$ post-infection in 3 fish (Nos. 2 to $4 ;$ when there were 1200000 to 1600000 parasites $\mathrm{ml}^{-1}$ blood) and at 5 wk post-infection in Fish No. 1 when there were

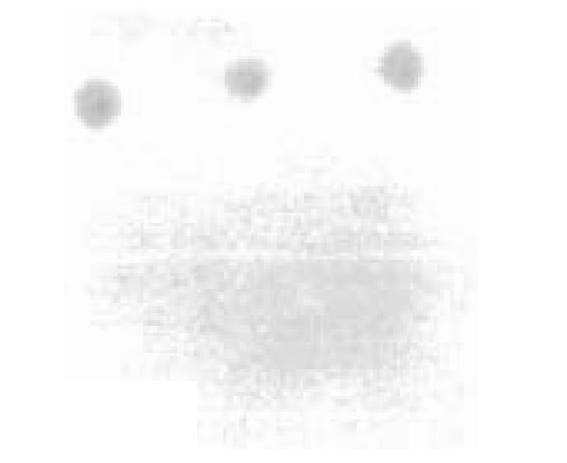

$f$

3

i

Fig. 3. Cryptobia spp. DNA hybridization in dried blood on filter paper (DBDB technique); each dot was from 2 filter paper disc (3 replications). Lane a: C. salmositica crude DNA; lane f: $C$. borreli crude DNA; lane g: $C$. bullocki crude DNA; lane h: C. catostomi crude DNA; lane i: naive trout blood DNA

900000 parasites $\mathrm{ml}^{-1}$ of blood. Subsequent determinations up to $11 \mathrm{wk}$ post-infection showed very similar results using the 2 techniques. Fish No. 4 from $8 \mathrm{wk}$ post-infection had low numbers of parasites and they were detected using the HCT but were negative using the DBDB technique.

\section{DISCUSSION}

The present results suggests that the Hind III restriction Cs-V1 fragments are highly repetitive and are Cryptobia salmositica-specific. One distinct C. salmositica-specific DNA fragment (approximately $1.2 \mathrm{~kb}$ ) was successfully cloned from nuclear DNA after it was cleaved using Hind III. The fragment (Cs-V1) after amplification was used to develop a DNA probe.

The Cs-V1 fragments hybridized specifically with purified or crude homologous target Cryptobia salmositica DNA. There were no cross-hybridizations with purified or crude nuclear DNA from $C$. borreli, $C$. bul-

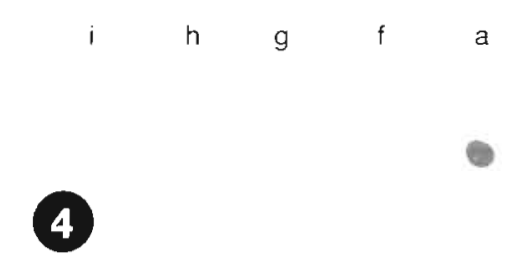

Fig. 4. Cryptobia spp. DNA dot blot hybridization with Cs-V1 probe. a: C. salmositica nuclear DNA $\left(7.5 \mathrm{ng} \operatorname{dot}^{-1}\right)$; $f: C$. borreli crude DNA (9.0 ng dot ${ }^{-1}$; mixed with carp DNA); g: $C$. bullocki nuclear DNA $\left(9.5 \mathrm{ng} \operatorname{dot}^{-1}\right) ; \mathrm{h}: \mathrm{C}$. catostomi nuclear DNA (8.9 ng); i: fish blood DNA $\left(6.7 \mu g \operatorname{dot}^{-1}\right)$ 


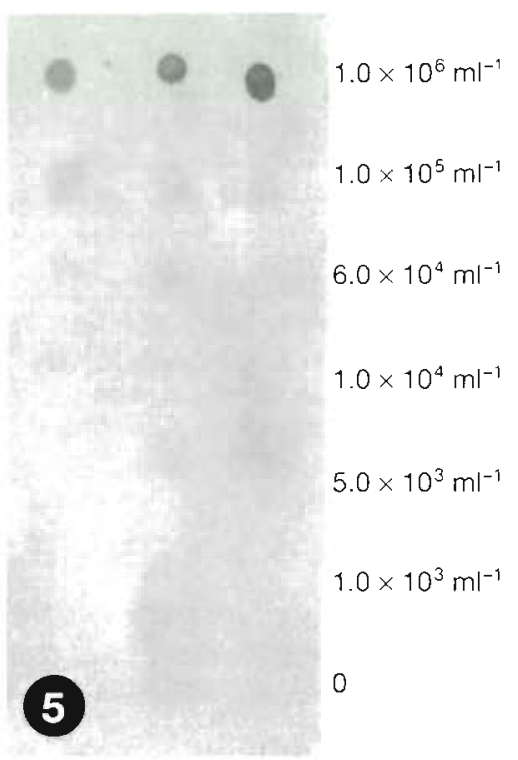

Fig. 5. Standardization of DBDB technique using trout blood with known numbers of Cryptobia salmositica dried on filter paperi each dot was from 1 filter paper disc ( 3 replications)

locki, C. catostomi and fish blood DNA. This indicates that the Cs-V1 fragment can be used as a DNA probe to distinguish C. salmositica from other species of Cryptobia. Similar results were also found in some species of mammalian trypanosomes; the highly repetitive species-specific DNA fragments constitute up to $9 \%$ of the total nuclear DNA (Gonzalez et al. 1984, Kirchhoff \& Donelson 1993). Hence, such highly repetitive DNA fragments are likely to be cloned and subsequently used as species-specific DNA probes (Massamba \& Williams 1984, Kukla et al. 1987).

Table 1. Detection of Cryptobla salmositica and parasite DNA in the blood of experimentally infected rainbow trout using the haematocrit centrifuge technique (HCT) and the dried blood DNA dot blot (DBDB) technique. For HCT, parasitaemias are given as positive $(+)$ where just detected or as $\times 1000000$ parasites $\mathrm{ml}^{-1}$ blood where measurable - ve: negative $\mathrm{DBDB}$ reaction; +ve: positive DBDB reaction; ND: not determined

\begin{tabular}{|c|c|c|c|c|c|c|c|c|}
\hline \multirow{2}{*}{$\begin{array}{l}\text { Weeks post- } \\
\text { infection }\end{array}$} & \multicolumn{2}{|c|}{ Fish No. 1} & \multicolumn{2}{|c|}{ Fish No. 2} & \multicolumn{2}{|c|}{ Fish No. 3} & \multicolumn{2}{|c|}{ Fish No. 4} \\
\hline & $\mathrm{HCT}$ & $\mathrm{DBDB}$ & $\mathrm{HCT}$ & DBDB & HCT & DBDB & $\mathrm{HCT}$ & $\mathrm{DBDB}$ \\
\hline 0 & 0 & $-v e$ & 0 & -ve & 0 & $-v e$ & 0 & -ve \\
\hline 1 & 0 & - ve & 0 & -ve & 0 & - ve & 0 & $-v e$ \\
\hline 2 & 0 & - ve & $(+)$ & -ve & $(+)$ & -ve & $(+)$ & $-v e$ \\
\hline 3 & 0 & - ve & 1.35 & +ve & 1.16 & +ve & 1.56 & +ve \\
\hline 4 & $(+)$ & -ve & 3.75 & ND & 2.88 & ND & 3.50 & ND \\
\hline 5 & 0.85 & + ve & 2.00 & ND & 1.00 & ND & 1.00 & ND \\
\hline 6 & 2.65 & tre & 0.63 & ND & $(+)$ & ND & 0.08 & ND \\
\hline 7 & 0.99 & ND & 0.24 & ND & $(+)$ & ND & 0.90 & ND \\
\hline 8 & 0.45 & +ve & 0.35 & +ve & $(+)$ & -ve & 0.43 & +ve \\
\hline 9 & 0.37 & +ve & 0.78 & $+v e$ & 0 & - ve & 1.40 & +ve \\
\hline 10 & 1.03 & tve & 2.50 & +ve & 0 & -ve & 0.90 & tve \\
\hline 11 & 2.05 & +ve & 0.70 & +ve & 0 & -ve & 0.38 & +ve \\
\hline
\end{tabular}

The present results indicate that the Cs-V1 probe is Cryptobia salmositica-specific, but not strain-specific. It may also be used for diagnosis of C. salmositica infection in rainbow trout. The DBDB technique, using dried blood from filter paper, was developed as a field technique to study the epizootiology of salmonid cryptobiosis. The technique can be used to identify the reservoir host(s) of C. salmositica and to determine the prevalence of infection in fish. Fish blood can be collected and dried on filter paper in the field and brought back to the laboratory for processing. The technique does not require DNA purification, and the blood sample collection and storage are relatively simple and rapid under field conditions.

The sensitivity of a DNA probe is related to the number of target DNA fragments and the method of labeling the probe (Barker 1994). Using a radioactive ${ }^{32} \mathrm{P}$ labelled nuclear DNA probe, trypanosome DNA was detected when there were 10000 (devoid of blood) or 100000 (mixed with host blood) trypanosomes per dot (Massamba \& Williams 1984, Gibson et al. 1988). In the present study, Cryptobia salmositica was detected in less than $0.02 \mathrm{ml}$ of the blood using a non-radioactive DIG-labelled probe when there were approximately 100000 parasites $\mathrm{ml}^{-1}$ blood. The detection using radioactive ${ }^{32} \mathrm{P}$-labelled probes is related to the number of copies of the $32 \mathrm{P}$ probe bound to the target DNA. However, the non-radioactive DIG-labelled probe is not only related to the number of target DNA fragments, but is also amplified by the antigen and antibody cascade reaction. This amplification increases its sensitivity (Hill et al. 1991). The polymerase chain reaction has been used to further increase the sensitivity of DNA detection (Sturm et al. 1989, Barker 1994), however, it is time-consuming to perform and it requires expensive and highly technical equipment (Barker 1994), which is at present not readily available in many laboratories.

The present study showed that the DBDB technique was less sensitive than the HCT for detection of Cryptobia salmositica in fish blood. However the HCT may not be a very practical field technique when large numbers of samples have to be examined in a relatively short time. Also the blood has to be kept cold and examined soon after collection (Woo \& Wehnert 1983). In the present study fish blood DNA mixed with the target $C$. salmositica DNA might have reduced the sensitivity of DBDB by covering some of the target DNA or by decreasing the amount of target DNA bound to the 
membrane as was suggested earlier for trypanosomes (Massamba \& Williams 1984). Nevertheless, the DBDB technique is a reliable and rapid method for the identification of C. salmositica although its use as a diagnostic technique may require further studies.

Acknowledgements. This study was supported by grants from the Department of Fisheries and Ocean (Canada) and the Natural Sciences and Engineering Research Council (Canada) to P.T.K.W.

\section{LITERATURE CITED}

Archer RK (1965) Haematological techniques for use on animals. Blackwell Scientific Publ, Oxford

Barker RH (1994) Use of PCR in the field Parasitol Today 10. $117-1.19$

Becker CD, Katz M (1965) Infections of the haemoflagellate, Cryptobia salmositica Katz 1951, in freshwater teleosts of the Pacific coast. Trans Am Fish Soc 94:327-333

Bower SM, Margolis L (1984) Detection of infection and susceptibility of different Pacific salmon stocks (Oncorhynchus spp.) to the haemoflagellate Cryptobia salmositica. $J$ Parasitol 70:273-278

Fairlamb AH, Weislogel PO, Hoeijmakers JHJ, Borst. P (1978) Isolation and characterization of kinetoplast DNA from bloodstream form of Trypanosoma brucei. J Cell Biol 76 : 293-309

Gibson WC, Dukes P, Gashumba JK (1988) Species-specific DNA probes for the identification of African trypanosomes in tsetse flies. Parasitology 97:63-73

Gonzalez A, Prediger E, Huecas ME, Nogueira N, Lizardi M (1984) Minichromosomal repetitive DNA in Trypanosoma cruzi: its use in a high-sensitivity parasite detection assay Proc Natl Acad Sci USA 81:3356-3360

Gradoni L, Grammicia M, Maroli M, Pozjo E, Bettini S (1983) A contribution to the technique of cloning Leishmania. Ann Parasitol Hum Comp 58:301-303

Heery DM Gannon F, Powell R (1990) A simple method for subcloning DNA fragments from gel slices. Trends Genet 6:173

Hill SM, Urwin R, Crampton JM (1991) A comparison of nonradioactive labelling and detection systems with synthetic oligonucleotide probes for the species identufication of mosquitoes in the Anopheles gambiae complex. Am J Trop Med Hyg 4 4:609-622

Katz M, Woodey JC, Becker CD, Woo PTK, Adams JR (1966) Records of Cryptobia salmositica from sockeye salmon from the Fraser River drainage and from the state of Washington. J Fish Res Bd Can 23:1965-1966

Kurchhoff LV, Donelson JE (1993) PCR detection of Trypanosoma cruzi, African trypanosomes, and Leishmania species. In: Persing DH, Smith TF, Tenover RC, White TJ (eds) Diagnostic molecular microbiology. American Society for Microbiology, Washington, DC, p 443-455

Responsible Subject Editor: W. Körtıng, Hannover, Germany
Kukla BA, Majiwa PAO, Young JR, Moloo SK, ole-Moiyoi O (1987) Use of species-specific IJNA probes for detection and identification of trypanosome infection in tsetse flies. Parasitology 95:1-16

Li S, Woo PTK (1991) In vitro effects of fetal bovine serum and glucose on multiplication of Cryptobia salmositica. J Parasitol $77: 151-1.55$

Li S, Woo PTK (1996) Effects of temperature and white sucker (Catostomus commersoni) serum supplement on the in vitro multiplication of Cryptobia catostomi in cell-free culture medium. Parasitol Res (in press)

Lynn DH, Sogin ML (1988) Assessment of the phylogenetic relationships among ciliated protists using partial ribosomal RNA sequences derived from reverse transcripts. Biosystems 21:249-254

Massamba NN, Williams RO (1984) Distinction of African trypanosome species using nucleic acid hybridization. Parasitology 88:55-65

Sakai DK (1981) Heat inartion of complements and immune haemolysis reactions in rainbow trout, Masu salmon, Coho salmon, goldfish and tilapia. Bull Jap Soc Scient Fish 47 : $565-571$

Sambrook J, Fritsch EF, Maniatis T (1989) Molecular cloning, 2nd edn. Cold Spring Harbor Laboratory Press, New York, p $1.34-1.41$

Southern E (1975) Detection of specific sequences among DNA fragments separated by gel electrophoresis. J Molec Biol 98:503-517

Sturm NR, Degrave W, Morel C, Simpson L (1989) Sensitive detection and schizodeme classification of Trypanosoma cruzi cells by amplification of kinetoplast minicircle DNA sequences: use in diagnosis of Chagas disease. Mol Biochem Parasitol 33:205-214

Woo PTK (1969) The haematocrit centrifuge for the detection of trypanosomes. Can J Zool 47:921-923

Woo PTK (1978) The division process of Cryptobia salmositica in experimentally infected rainbow trout (Salmo gairdneri). Can J Zool 56:1514-1518

Woo PTK (1979) Trypanoplasma salmositica: experimental infections in rainbow trout Salmo gairdneri. Expl Parasitol $47: 36-48$

Woo PTK (1987) Cryptobia and cryptobiosis in fishes. In: Baker JR, Muller R (eds) Advances in parasitology, Vol 26. Academ.c Press, London, p 199-237

Woo PTK (1994) Flagellate parasites of fish. In: Kreier JP (ed) Parasitic protozoa, Vol 8. Academic Press, New York, p $1-80$

Woo PTK, Li S (1990) In vitro attenuation of Cryptobia salmositica and its use as a live vaccine against cryptobiosis in Oncorhynchus mykiss. J Parasitol 76:752-755

Woo PTK, Thomas PT (1991) Polypeptide and antigen profiles of Cryptobia salmositica, C. bullocki and C. catostomi (Kinetoplastida: Sarcomastigophora) isolated from fishes. Dis Aquat Org 11:201-205

Woo PTK, Wehnert SD (1983) Direct transmission of a haemoflagellate, Cryptobia salmositica Katz, 1951 (Kinetoplastida: Bodonina) between rainbow trout under laboratory conditions. J Protozool 39:334-337

Manuscript first received: June 14, 1995

Revised version accepted: November 14, 1995 